\title{
Proposing Models of Mutual Cooperation between Parents and Teacher during Pandemic Era
}

\author{
Elka Anakotta \\ \{anakottaelka@gmail.com\} \\ Institut Agama Kristen Negeri Ambon
}

\begin{abstract}
Mutual cooperation between parents and teachers are required in school, especially during the pandemic era with online learning or school. This article intentions to proposing the models of mutual cooperation between parents and teacher in online learning or school in elementary because without it the learning development will not succeed. This article engaged with library research and all data comes from e-book, journals, articles, virtual resources and internet access to propose the model of mutual cooperation between parents and teacher. This article concludes that effectively cooperation between parents and teacher with certain model will make online learning or school going well. It is recommended that parents and teacher may conduct a model of mutual cooperation in online school.
\end{abstract}

Keywords: Mutual cooperation parents and teacher; pandemic era; online school

\section{Introduction}

Quoted from BBC News. Com (downloaded at June, 10 ${ }^{\text {th }}$ 2021), in May, 22th 2021, corona virus disease casualties total death are 3,4 million and 165,5 confirmed case. Even, according to this news, While Covid 19 rages in India, scientist already recommend about further flash inescapable. Approximately 4.000 people passed away and the third wave shall India covering. Educational institutions closing pro time in most states to block the covid 19 virus escalation. Online communications applications include online classes being used to ensure communication between teachers and students and facilitating the continuity of education.

In Indonesia, according to Abidah article, the Ministry of Education and Culture (MOEC) composing the way out with all schemes along with the application of working together to reassure online learning (in networks) for students. One of the forms that was initiated by the Ministry with develop distance education appliscations established on android called "Portal Rumah Belajar". Other models provided are Smart Classes, Quipper, Google Indonesia, Sekolahmu, Zenius, and Microsoft. Each of them will maintain publicly free and accessible, so it could be pervaded by students and teachers to advance learning belongings.[1].

But, the problem doesn't stop with the forecast, because a recent study of Bueno 2020 (in Carretero et al., 2021) shows that result of cognitive and behavioural children perform lower in entire day virtual learning. Comparing with face to face learning, this study shows in 
primary and secondary school, have learning losses and have a lower feasibility to graduate.[2].

The criticism from student's parents about their stressing through The Indonesian Child Protection Commission (KPAI). The sources of their stressing in home study program are diverse of coursework all along and the chance to complete the course in short time only. This makes children tired. In responding this problematic, remodelling the partnership between teacher and parents (families) required, because they have very similar goals for their children to develop fruitful with their schooling. [3]. In many studies (Epstein and Levanda in Xiaoyang et al., 2018) the accomplishment of student inspired by parents participation. In case parents elaborate in children learning progression, they will have higher requirement rates and will success at school. [4].

Several years ago, to build close relationship between teachers and students (and of course their parents), they do by appointment their students home. Now, the changing circumstances for many reasons, there is no time for teacher to spend time in the school community and recognize themselves with it. According to Keyes (in Rusnak \& Rusnak, 2020), the changing of socioeconomic classification or values have an impact and build blocks to emergent actual corporations between teachers and parents. The other side, as lifetime process, being a parent never been relaxed, somehow they sense uncorroborated, adjudicated and misjudged by educators. In Rusnak research, the common of parents deliberate their failure in parenting, because instead of giving support, the school forceful and not assistance parents to do their job well.[5].

Carretero (Carretero et al., 2021) show how the condition of the first COVID-19 lockdown testify the readiness of teachers and students in online learning, likewise the capability digital level of parents, who turn into more elaborate their children learning process. In Poland for example, the parents stressed with zooming the file with children assignments, because in working they just using simple tasks on the computer. They admit that they tested and must learn more with all these platforms. [2]. Previously also submitted by Epstein (in Xiaoyang et al., 2018), many parents are unaware to support their children with homework and other activities connected with the curriculum. Even though, with balancing cooperative with teachers, parents can encouragement students to make their school activities complete.[4].

Partnerships advance in connecting parents (families) with school climate and programs, increase skills and management to support teachers with their work in home. The main purpose is to help children prosper in school and in future life.[6]. In other article, Coleman (in $\mathrm{Li}$ et al., 2019) stated that parent-teacher interface as opportunity to exchange important information, support each other of mutual obligation and trust, to aid students prosper. Exposed communication between home and school combines the advance of successful children in academic.[7].

Understanding the importance of parents involvement to their children education, especially during the pandemic era, will make a meaningful contribution to how rebuild parents-teacher relationships in creating a good and conducive atmosphere for children in carrying out online school process. Because with online schools, all the time the children are being at home with parents or other companions in the family, so of course a good collaboration between teachers and parents is needed so the online school process can be useful and have a good impact on children's development. This article will explore how parents and teacher will build the mutual cooperation which have a direct impact to children success in online school in pandemic era. 


\section{Method}

This research used library research, to gather and analyse the data. The researcher will explanation and mixes with notions to synthesize the conclusion. Books and journals will be used as resources, focused on the analysis the mutual cooperation from parents and teacher built especially in pandemic era, because children must stay at home and make online school. The researcher used journals in recent pandemic era to put the problem properly and understanding the situation better. Several journals and books before the pandemic era are data to built the theory that useful while analyse how the mutual cooperation must be realized.

\section{Result and Discussion}

According to Bronfenbrener (in Pirchio et al., 2013), partnership between parents and teachers having an impact for children's advance. From ecological perspective about human development, safety home must facilitate the child's development to offer an intelligible educational atmosphere.[8]. So, parents must receipts the responsibilities and must strive to understanding the role they should play in online leraning (Boulton, 2008; Murphy \& Rodriguez-Manzanares, 2009 in Garbe et al. 2020). Several tasks may bearing to this role (Povey 2016 in Garbe at al., 2020), such as economic capitals, internet access deficiency, limited knowledge in using technology, and less self-efficacy in digital. In pre-pandemic while do online learning (Hasler Waters \& Leong, 2014 in Garbe et al, 2020), parents become a learning tutor for students (their children as virtual learner) who apply a significant role such as establishing students' agendas, development relationships and connections students as necessary.[9].

In determining partnership, teachers and school administrators generate more family-like schools, then each child's individuality recognizing well and each child will feel special in their way. In other side, parents generate also school-like families, then each child is also a student at home. The families know exactly the standing of school, school activities, and impact in skill and successful feeling for student. The School and parent working together, generate activities that strengthen students development. Community- minded families and students help their neighbourhoods and other families. This is how community school will remerging.[6].

To build a good working relationship between teachers and parents many problem must faced (Bakalar 2018 in Rusmiati et al., 2020), among others school infrastructure (internet system) especially in villages, as well as the cost of acquiring the packages of expensive data, bad signals, the sending materials to children and the sending tasks to teacher. Indonesian government lately supplied about the regulation that their will supply data packages, schools still not entirely like online learning (school from home). To do school from home, parents can contribute to the process in understanding subject matter while the children not understood or conveyed well by a teacher. To make this good, at least parents support the hardware that their children requirement in online learning such as cellular phones or laptops. Then, what is the teacher's role in this process? According to Rusmiati, teachers must provide instructional workings to students include instructional methods and media in the process. The changing process in online learning (from face to face before) make them have several tasks related with technical problems, which if it can't be overwhelmed then student participation will become not optimal. Students with low wconomic level will facing these technical problems frequently.[10]. 
Reorganize of online learning requests to provide the anti plagiarism and evade cheat in the process of exams, home tasks, and other activities. To save the education process, there must be quality assurance of the online teaching method. Teaching method have to be intentional and enhanced, including the accessible utensils and platforms that used. For example the integration between the google meet system and google classroom platform, or the laboratory preparation simulators for learning in STEM courses. The country needs to approximate the successful of the process for the whole country or the world. [11]. Education system in national or local education focusing in established technology rapidly, so home learning settings established. They are already used digital learning platforms had less barriers to associated with schools that had previously made little custom of technology or where students did not have devices and the internet at home.[12].

Earlier study results (Megawati in Lase et al., 2020) that direct teaching with face to face learning make the students simply know the material faster, because they can relate and study together. Adnan and Anwar (in Lase et al., 2020) even show that $78.6 \%$ of respondents felt that conservative classes (face to face learning) are more effective than online learning. But of course, there is no other way to choose online learning as solution in pandemic (Herlinadry in Lase et al., 2020). Online learning with all demands asking for parents to make adjustment to all the condition including economic condition and a good internet network that supports the online learning process.[13]. But parents have no other choice, because as literature displays also that their contribution in children activities (no matter direct or indirect or online) will increase social and academic development. [8].

As Guner (2019 in Rusmiati et al., 2020) set up that in school from home (or online learning) need funding from parents, teachers, and government, in several elements, one of them is support the training of teachers in with technology and designing online learning. The other, support the participation of parents, teachers, and the school by making a communal of knowledge to comprehend how online learning process. This is include synergizing collaboratively learning material in this system, and collaboration is also indispensable to effective online learning. The teamwork among teachers will support to discovery answers in correcting material and sharing the experience in motivating students while their get bored during online learning.[10].

Parent involvement contains several forms of contribution, such as joining in school program (seminars or conferences for example), so that they can involving more in support their children, demonstrating desired behaviour, monitoring while children do their homework, and tutoring their children at home.[14]. Not surprisingly, Bara (2015) mentioned that parents as "key actors" that have great influence in teaching institution. Then, the creation of a vigorous partnership with parents will empower a helpful communication, giving their support with valuable advice also their materials support to schools. If the cooperation inadequate then will has negative significances in teaching and learning process.[15].

Shore (2020 in Belgica et al., 2020) mentioned in his article that an online class removes the human linking and the motivation of student, and the worst is the lost of interaction between teacher and children. Friedman (2020 in Belgica et al., 2020) in more specific pointed out that tasks in online learning includes technical problems, disruption and time management, how to stay motivating, understanding learning goals, lack of in-person communication, adapting to unaccustomed technology, and doubt about the forthcoming. Both of them (Shore and Friedman) obviously definite that there are diverse tasks usually encountered by students in their online learning.[16].

When parents and children cooperate in learning activities, bonding between them will growths as they are able to apply more time together. Parents converted a source to ease the 
pain and worry of their children during online learning. Then parents should be qualified in involvements to support uncertainty times of children. Online learning system with supporting parents might helpful the bond between children and their parents. What can they do together? Bhamani mentioned about doing arts and crafts, cooking, dancing, singing, and so on. These activities will open the way to become more closer, so they will keep supporting on academic activities also. But apparently, it doesn't stop there because a lot of children seeing these times as break from school. Then, they just do whatever they like, as sleep and play all long without physical activities. This is the problem too. The problem faced by the children. There is also the problem for parents with their activities from being lock down.[17].

How to anticipate evading situation, from Epstein (in Islahuddin et al., 2016) point of view there are six roles must be occupy by the family in education namely parenting, communicating, volunteering, learning at home, decision-making, and collaborating with the community. [18]. Each role offerings particular encounters that must involve all families and required some basic principles of participation. Each role is likely lead to differ results for students, parents, teaching practices, and school climates.[6].

Furthermore, Epstein 2009 (in Newchurch, 2017) putting learning at home in fourth type to offer notions to families in support children learning including schoolwork and other activities, in making decision, even in planning. Learning at home according to Epstein will reassured children to discussing assignments and ideas with family members, encourage their children in making goals for successful education, and in planning further educational. Children are given chance to demonstrate what they are earned from the class, accomplish their assignments, advance their competence, and parents must alert curriculum or program of the school. But unfortunately many parents are uninformed about how to support their children with schoolwork and other school activities. The effectiveness of learning at home results have good impact to students, parents, even an educators. The support of families at home to children increase the capabilities of students (such as get high scores in test), and the benefit for parents having better considerate of the curriculum, easier to support children with curriculum. For teachers and schools may recognise to motivating students from all backgrounds with strengthening in the their home [19].

From Swap (1992 in Steh \& Kallin, 2011), he founding an model of the relationship between parents and schools, with three approach of parental participation. Number one is he called protective model. The goal of this model is to evade problem between teachers and parents by separating the functions of parenting and teaching. This model defends the school from parents interruption, so teacher have full responsibility to educate children, and the parent's just making sure that children get to school right on time with their complete equipment. So, parental involvement needless in this model. Number two is transmission model on the opinion that teachers play an important role but still receives supporting from parents in enabling the progress of children. Teachers using methods to mentoring parents in build productive relationships. This model has the possibility to parents to perform the school activities in home. Number three is curriculum enrichment model grounded on the assumption that parents have value asset to support teachers in improve the curriculum. Parent will effort primarily on curriculum and instruction from schools. [20].

Turnbull and colleagues (2011 in Durisic \& Bunijevac, 2017) summarized several principles in partnership parents and school effectiveness. The basic is trust, the teacher is enforced to have an honest and mutual respect in relationships with parents. Parents should be persuaded about the capability of the teacher as professional in their duty. Another principle is two way communication between parents and teachers to exchange ideas between them. 
Finally, is the imperative of caring and protecting children achieved through early identification of problems, the solution, and choosing appropriate methods about the protection of children. [21].

Based on what has been described above, how should we build a mutual relationship between parents and teacher, especially during pandemic era? There are at least three things that must be build from parent's side, communication, interaction and participation. Parents must be ready to obtain and accommodate information from school whether as parents is busy or not with their work. The information received can be in various forms, concerning the subject of children's lessons, activities that must be carried out, other activities other than academic activities, tasks that must be done and also about development of children in learning process.

After take the information, parents must respond to the information, by providing what children needs in accordance with the information received but responding to the teacher or school as a source of information. In normal situation (not in pandemic), parents can directly meet teachers, for example in school or through special meetings that have been designed by the school for that. Furthermore, parents can arrive at an active form of participation and become very aware of the interests and conditions of the child that must be available during the learning process. In relation to online learning, more readiness from parents is needed, including readiness to provide internet access, understand how to manage it, and apply it in the learning process.

In pandemic era, total time the child spends at home. The child will start and end the whole series of learning at home. If the teacher gives a lecture on a certain topic, it takes full concentration from the child in accepting it, so every parents must make the home as comfortable as possible so that the child can follow the learning school well. So, it can be imagined, if in the family there are several children who are simultaneously doing online learning, the of course it needs media (gadget or laptop and internet) but also the readiness of an adequate study room for children. In this position, the family's economic condition also supports the success of online learning. What is the teacher's position in a process like this? Will the teacher then the only be the main source of information in the learning process and students will complete the assignments that have been considered by the teacher? Will the online learning be successful and have a good impact on children? In the middle or high school students, this process is easier to passed because they have been conditioned in the face-to-face process before, but elementary school children will definitely have a hard time dealing with this. This situation at home makes them not have feel at school so they can play more with what is around them as they usually do at home. Feeling that change because they feel isolated from a good environment school and at home will further exacerbate this situation. If parents lose control and control, it is very likely that there will be failure in the online learning process. Parents have a big responsibility to be an extension of the teacher at home. Parents become teacher at home.

What must be built in schools to make parents as teachers at home must be built through an integrated school system and conditions for this to happen. This means that the willingness of teachers to become a mutual relationship with parents is only possible if the school provides these conditions.

\section{References}

[1] A. Abidah, H. N. Hidaayatullaah, R. M. Simamora, D. Fehabutar, and L. Mutakinati, 
"The Impact of Covid-19 to Indonesian Education and Its Relation to the Philosophy of 'Merdeka Belajar,"' Stud. Philos. Sci. Educ., vol. 1, no. 1, pp. 38-49, 2020, doi: 10.46627/sipose.v1i1.9.

[2] S. Carretero et al., What did we learn from schooling practices during the COVID-19 lockdown? 2021.

[3] P. Support et al., "Study From Home In The Middle Of The COVID-19 Pandemic: Analysis Of Religiosity, Teacher, and Parents Support Against Academic Stress," J. Talent Dev. Excell., no. June, 2020.

[4] Y. Xiaoyang, G. K. Sidhu, and P. K. Veloo, "Parents' Perspectives on School and Family Cooperation in Primary Schools: A Case Study in China," Turkish Online J. Des. Art Commun., vol. 8, no. SEPT, pp. 1263-1269, 2018, doi: 10.7456/1080sse/169.

[5] M. Rusnak and M. Rusnak, "Teachers Parents," no. 676452, 2020.

[6] L. Joyce, G. Mavis, S. Beth, K. Clark, N. Rodriguez, and L. Frances, School, family, and community partnerships-caring for the children we share. 2018.

[7] G. Li, M. Lin, C. Liu, A. Johnson, Y. Li, and P. Loyalka, "The prevalence of parentteacher interaction in developing countries and its effect on student outcomes," Teach. Teach. Educ., vol. 86, p. 102878, 2019, doi: 10.1016/j.tate.2019.102878.

[8] S. Pirchio, Y. Passiatore, C. Tritrini, and T. Taeschner, "The Role of the Relationship between Parents and Educators for Child Behaviour and Wellbeing," Int. J. about Parents Educ., vol. 7, no. 2, pp. 145-155, 2013.

[9] A. Garbe, U. ogurlu, N. Logan, and P. Cook, "Parents' Experiences with Remote Education during COVID-19 School Closures," Am. J. Qual. Res., vol. 4, no. 3, pp. 4565, 2020, doi: 10.29333/ajqr/8471.

[10] A. R. Rusmiati et al., "The perceptions of primary school teachers of online learning during the COVID-19 pandemic period: A Case study in Indonesia," J. Ethn. Cult. Stud., vol. 7, no. 2, pp. 90-109, 2020.

[11] G. Basilaia and D. Kvavadze, "Transition to Online Education in Schools during a SARS-CoV-2 Coronavirus (COVID-19) Pandemic in Georgia," Pedagog. Res., vol. 5, no. 4, 2020, doi: 10.29333/pr/7937.

[12] S. Bubb and M. A. Jones, "Learning from the COVID-19 home-schooling experience: Listening to pupils, parents/carers and teachers," Improv. Sch., vol. 23, no. 3, pp. 209222, 2020, doi: 10.1177/1365480220958797.

[13] D. Lase, S. E. Zaluchu, D. O. Daeli, and A. Ndraha, "Parents' Perceptions of Distance Learning during Covid-19 Pandemic in Rural Indonesia," no. December, 2020, doi: 10.35542/osf.io/hfza7.

[14] G. Bador and O. Delarue, "The Nansen Refugee Award," Refug. Surv. Q., vol. 22, no. 1, pp. 48-51, 2003, doi: 10.1093/rsq/22.1.48.

[15] G. Bara, "The Partnership between the School and Parents," vol. 5, no. 9, pp. 1-5, 2015.

[16] C. C. Belgica, J. A. Calugan, J. U. Dumo, and L. A. Simber, "Online Distance Learning: Thematic Study on the Challenges Faced By Educare College Inc . Primary Pupils Abstract :," pp. 1-18, 2020.

[17] S. Bhamani, A. Z. Makhdoom, V. Bharuchi, N. Ali, S. Kaleem, and D. Ahmed, "Home Learning in Times of COVID: Experiences of Parents," J. Educ. Educ. Dev., vol. 7, no. 1, p. 9, 2020, doi: 10.22555/joeed.v7i1.3260.

[18] Islahuddin, I. Tolla, and Mansyur, "A holistic model of partnership in education," Int. J. Environ. Sci. Educ., vol. 11, no. 13, pp. 5915-5924, 2016.

[19] A. Newchurch, "The impact of parental Involvement on student success: School and 
family partnership from the perspective of parents and teachers," Thesis, vol. 2017, pp. 1-183, 2017.

[20] B. Šteh and J. Kalin, "Building partner cooperation between teachers and parents," Cent. Educ. Policy Stud. J., vol. 1, no. 4, pp. 81-101, 2011.

[21] M. Đurišić and M. Bunijevac, "Parental involvement as a important factor for successful education," CEPS J., vol. 7, no. 3, pp. 137-153, 2017. 